\title{
Geriatric giants - contemporary occurrence in 12,210 in-patients
}

\author{
Weber $\mathrm{P}^{1}$, Meluzinova $\mathrm{H}^{1}$, Matejovska-Kubesova $\mathrm{H}^{1}$, Polcarova $\mathrm{V}^{1}$, Jarkovsky $\mathrm{J}^{2}$, Bielakova $\mathrm{K}^{1}$, \\ Weberova $\mathrm{D}^{1}$
}

Department of Internal Medicine, Geriatrics and Practical Medicine, Faculty Hospital and Masaryk University, Brno, Czech Republic. p.weber @ fnbrno.cz

\begin{abstract}
OBJECTIVES: With advancing age, the degree of dependency and occurrence of great geriatric syndromes (GS), also referred to as geriatric giants, grow substantially.

DESIGN: The prospective cohort study was aimed at conducting an analysis and comparison of geriatric syndromes (geriatric giants) among different age groups at admission to the acute geriatric department.

SETTING, PARTICIPANTS: Between 1995 and 2012, we had altogether 12,210 elderly patients at an average age of $80.5 \pm 7.0 \mathrm{y}$ (range 65-103 y) hospitalised at the Department of Geriatrics. We divided the patient set into three different age subgroups (65-74 y; 75-84 y and $\geq 85$ y; e.g. $21.4 \%$; $47.9 \%$ and $30.7 \%$ ) and compared the results among them.

RESULTS: 3,787 persons (31.0\%) were without any GS. The growing tendency of the occurrence of all geriatric syndromes in combinations with increased age $(p<0.001)$ is obvious. Their occurrence in the above mentioned different age sets was examined in relation to individual geriatric syndromes and sex (female and male), namely falls $22.0 \%, 27.8 \%, 39.9 \%$ and $20.5 \%, 27.0 \%, 36.1 \%$; immobility $26.4 \%, 29.3 \%, 42.5 \%$ and $30.3 \%, 30.1$ $\%$ and $39.2 \%$; incontinence $38.4 \%, 50.6 \%, 69.5 \%$ and $38.2 \%, 47.4 \%, 61.8 \%$; dementia and cognitive impairment $13.4 \%, 23.4 \%, 38.1 \%$ and $15.8 \%, 24.3 \%, 33.2 \%$ respectively. Age cut-off for geriatric syndromes occurrence based on ROC analysis is $83.5-84.5 \mathrm{y}$ for females and $78.5-82.5 \mathrm{y}$ for males.

CONCLUSION: The occurrence of geriatric giants increasing with age and female gender is of crucial importance not only for individuals and families but also for demands on costs of health and social care in oncoming decades (Tab. 6, Fig. 3, Ref. 52). Text in PDF www.elis.sk.

KEY WORDS: advanced age, geriatric syndromes, falls, dependency.
\end{abstract}

\section{Introduction}

Health status in ageing is a result of many factors including chronic diseases of ageing and many other prevalent conditions that cannot be defined as classic diseases because they do not result from a single pathologic cause. Many of problems affecting the aged individuals should be viewed as main geriatric syndromes (GS) or geriatric giants that are a collection of signs and symptoms with a number of potential causes (1). The increasing occurrence of geriatric giants appearing with age is of crucial importance and could have serious consequences not only for individuals and families but also for demands on and costs of health and social care $(2,3)$. It is important in planning for the needs of older people to have projections based on reliable estimates of the prevalence and incidence of geriatric giants and associated disability. Comprehensive evaluation (4) is usually required to identify and treat underlying causes.

${ }^{1}$ Department of Internal Medicine, Geriatrics and Practical Medicine, Faculty Hospital and Masaryk University, Brno, Czech Republic, and ${ }^{2}$ Institute of Biostatistics and Analysis, Masaryk University, Brno, Czech Republic

Address for correspondence: $\mathrm{P}$. Weber, MD, PhD, Dept of Internal Medicine, Geriatrics and Practical Medicine, Faculty Hospital and Masaryk University, Jihlavska 20, CZ-625 00 Brno, Czech Republic.

Phone/Fax: +420.5 .32232509$
GS are common in elderly patients that are admitted to an acute care hospital $(5,6)$, but may not be adequately assessed and managed. The most likely explanation for a nonspecific presentation is that the additive effects of ageing restrict the capacity to maintain homeostasis (7). The blunting or absence of typical or classic symptoms and signs is well described in many conditions $(7,8)$.

In spite of indisputable significance of the atypical clinical picture of diseases in old age, the crux of geriatric medicine is the complexity conditioned by the decline of health potential, frailty and related geriatric syndromes as well as functional deficiency with their multi-causal reasons $(8,9)$. GS among the elderly (particularly in the subset of "oldest-of-old") hospitalized patients diminish their quality of life.

The aim of our prospective cohort study was targeted at conducting an analysis and comparing the occurrence of GS individually and in combinations in relation to gender and age in sub-files of different age groups. A good understanding of their occurrence could be essential for planning acute elderly hospital care (10).

\section{Patients and methods}

Between 1995 and 2012 we had altogether 12,210 elderly patients at an average age of $80.5 \pm 7.0 \mathrm{y}$ (range $65-103 \mathrm{y}$ ) hospitalised at the Department of Geriatrics. Out of this number there 
Tab. 1. Description of the dataset structure.

\begin{tabular}{|c|c|c|c|}
\hline & Female & Male & Total \\
\hline Number of patients & $8.134(66.6 \%)$ & $4.076(33.4 \%)$ & 12.210 \\
\hline Age $^{1}$ & $81.2 \pm 7(65-103)$ & $79.3 \pm 7(65-101)$ & $80.5 \pm 7(65-103)$ \\
\hline $65-74$ yrs & $1.512(12.38 \%)$ & $1.103(9.0 \%)$ & $2.615(21.4 \%)$ \\
\hline $75-84$ yrs & $3.876(31.74 \%)$ & $1.969(16.1 \%)$ & $5.845(47.9 \%)$ \\
\hline$\geq 85$ yrs & $2.746(22.49 \%)$ & $1.004(8.2 \%)$ & $3.750(30.7 \%)$ \\
\hline
\end{tabular}

were 8,134 women $(66.6 \%)$ and 4,076 men (33.4\%) (Tab. 1). All the patients were admitted non-selectively from their catchment areas of Brno city where 120,000 inhabitants live. They were admitted from GPs, internists or other outpatient's departments via emergency room. We have 63 acute geriatric beds for admission of outside patients available.

No geriatric giants were present for neither of genders in 3,787 cases $(31.0 \%)$; in female patients the total was 2,374 cases $(29.2$ $\%$ ) and that in the males was 1,413 cases (34.7\%) (Tab. 3). All the data were prospectively collected and later on statistically analysed.

All the patients admitted at the geriatric department underwent complete intern examination, X-ray of lungs, ECG, basic biochemical and haematological analyses, and were subjected to various additional examinations (CT, NMR, ophthalmological, neurological etc.) depending on individual indication.

In the whole patient set an occurrence of geriatric giants, such as falls (minimally once in the past year), immobility, incontinence and dementia were assessed. Falls are taken into account should they take place in the past year before the admission date. The immobility was defined as being confined to bed or to wheelchair. Incontinency was defined as any unintended leakage of urine. Further on, there were following items assessed, such as ADL (activity of daily life) - test according to Barthel at the time of admission and discharge, mobility, and mini mental state examination (MMSE) - test according to Folstein at the time of admission and discharge with an emphasis on assessing cognitive functions, while further examinations (CT, NMR, SPCET of brain, EEG, ultrasound of main brain vessels etc.) were performed according to the clinical status and medical need, when cognitive functions were changed or decreased. The results had been carefully considered before the diagnosis of dementia was pronounced. According to the social sphere oriented scales and objective examination, we analysed also loneliness, need of aftercare, nursing home admission, dependency and malnutrition.

The comparison among different age groups was carried out. Further on, there were standard geriatric tests and scales performed to obtain geriatric assessment (ADL; Norton; Mini Nutritional Assessment Short Form/MNA-SF; MMSE; CAM; mobility-tests etc.).

We have analysed a data set of patients hospitalized at the Department of Geriatrics. These patients have been divided into six groups according to their sex (female, male) and age (65-74 years, 75-84 years and over 85 years) (Tab. 1). The occurrence of various geriatric syndromes has been compared between males and females of different age, and between males and females altogether.

The occurrence of syndromes in groups of patients has been described by a number of cases and percentage of patients in the
Tab. 2. Occurrence of geriatric syndromes according to age and sex.

\begin{tabular}{|c|c|c|c|}
\hline & Female & Male & $\mathrm{p}^{1}$ \\
\hline \multicolumn{4}{|c|}{ Fall in last year } \\
\hline $65-74$ yrs & $332(22.0 \%)$ & $226(20.5 \%)$ & 0.384 \\
\hline $75-84$ yrs & $1,077(27.8 \%)$ & $531(27.0 \%)$ & 0.515 \\
\hline$\geq 85 \mathrm{yrs}$ & $1,096(39.9 \%)$ & $362(36.1 \%)$ & 0.034 \\
\hline $\mathrm{p}^{2}$ & $<0.001$ & $<0.001$ & \\
\hline \multicolumn{4}{|l|}{ Immobility } \\
\hline $65-74$ yrs & $399(26.4 \%)$ & $334(30.3 \%)$ & 0.031 \\
\hline $75-84$ yrs & $1,137(29.3 \%)$ & $593(30.1 \%)$ & 0.544 \\
\hline$\geq 85 \mathrm{yrs}$ & $1,168(42.5 \%)$ & $394(39.2 \%)$ & 0.073 \\
\hline $\mathrm{p}^{2}$ & $<0.001$ & $<0.001$ & \\
\hline \multicolumn{4}{|c|}{ Incontinence } \\
\hline $65-74$ yrs & $580(38.4 \%)$ & $421(38.2 \%)$ & 0.935 \\
\hline $75-84$ yrs & $1,962(50.6 \%)$ & $933(47.4 \%)$ & 0.020 \\
\hline$\geq 85 \mathrm{yrs}$ & $1,908(69.5 \%)$ & $620(61.8 \%)$ & $<0.001$ \\
\hline $\mathrm{p}^{2}$ & $<0.001$ & $<0.001$ & \\
\hline \multicolumn{4}{|l|}{ Dementia } \\
\hline $65-74$ yrs & $203(13.4 \%)$ & $174(15.8 \%)$ & 0.102 \\
\hline $75-84$ yrs & $906(23.4 \%)$ & 478 (24.3\%) & 0.454 \\
\hline$\geq 85$ yrs & $1,046(38.1 \%)$ & $333(33.2 \%)$ & 0.006 \\
\hline $\mathrm{p}^{2}$ & $<0.001$ & $<0.001$ & \\
\hline \multicolumn{4}{|l|}{ Loneliness } \\
\hline $65-74$ yrs & $944(62.4 \%)$ & $420(38.1 \%)$ & $<0.001$ \\
\hline $75-84$ yrs & $2,936(75.8 \%)$ & $873(44.3 \%)$ & $<0.001$ \\
\hline$\geq 85 \mathrm{yrs}$ & $2,320(84.5 \%)$ & $590(58.8 \%)$ & $<0.001$ \\
\hline $\mathrm{p}^{2}$ & $<0.001$ & $<0.001$ & \\
\hline \multicolumn{4}{|c|}{ Need of aftercare } \\
\hline $65-74$ yrs & $236(15.6 \%)$ & $153(13.9 \%)$ & 0.221 \\
\hline $75-84$ yrs & $736(19.0 \%)$ & $318(16.2 \%)$ & 0.008 \\
\hline$\geq 85 \mathrm{yrs}$ & $682(24.8 \%)$ & $199(19.8 \%)$ & 0.001 \\
\hline $\mathrm{p}^{2}$ & $<0.001$ & $<0.001$ & \\
\hline \multicolumn{4}{|c|}{ Nursing home admission } \\
\hline $65-74$ yrs & $27(1.8 \%)$ & $22(2.0 \%)$ & 0.771 \\
\hline $75-84$ yrs & $128(3.3 \%)$ & $45(2.3 \%)$ & 0.033 \\
\hline$\geq 85 \mathrm{yrs}$ & $183(6.7 \%)$ & $39(3.9 \%)$ & $<0.001$ \\
\hline $\mathrm{p}^{2}$ & $<0.001$ & 0.012 & \\
\hline \multicolumn{4}{|c|}{ Dependency - admission } \\
\hline $65-74$ yrs & $618(40.9 \%)$ & $457(41.4 \%)$ & 0.778 \\
\hline $75-84$ yrs & $1,837(47.4 \%)$ & $893(45.4 \%)$ & 0.142 \\
\hline$\geq 85 \mathrm{yrs}$ & $1,723(62.8 \%)$ & $568(56.6 \%)$ & 0.001 \\
\hline$\underline{\mathrm{p}^{2}}$ & $<0.001$ & $<0.001$ & \\
\hline \multicolumn{4}{|c|}{ Dependency - discharge } \\
\hline $65-74$ yrs & $439(29.0 \%)$ & $334(30.3 \%)$ & 0.515 \\
\hline $75-84$ yrs & 1,290 (33.3\%) & $646(32.8 \%)$ & 0.724 \\
\hline$\geq 85 \mathrm{yrs}$ & $1,326(48.3 \%)$ & $446(44.4 \%)$ & 0.039 \\
\hline $\mathrm{p}^{2}$ & $<0.001$ & $<0.001$ & \\
\hline \multicolumn{4}{|c|}{ Malnutrition } \\
\hline $65-74$ yrs & $1512(9.0 \%)$ & $1,103(11.0 \%)$ & 0.097 \\
\hline $75-84$ yrs & $3,876(11.3 \%)$ & $1,969(12.8 \%)$ & 0.095 \\
\hline$\geq 85 \mathrm{yrs}$ & $2,746(20.9 \%)$ & $1,004(21.5 \%)$ & 0.684 \\
\hline $\mathrm{p}^{2}$ & $<0.001$ & $<0.001$ & \\
\hline
\end{tabular}

${ }^{1}$ Statistical significance of difference between men/women within given age group was assessed by Fisher exact test, ${ }^{2}$ Statistical significance of difference among age groups within men/women assessed by Kendall tau test

group. Statistical significance of difference in the occurrence of geriatric syndromes between male and female patients of the same age group has been assessed by Fisher exact test. Kendall tau test for ordered categories has been used for comparison among age groups.

Later on, ROC analysis has been performed, and its AUC value (range $0.5-1.0$; higher value means better discrimination power), associated p-values, selected cut-off of predictor for given geriatric syndrome/combination, and its sensitivity and specificity 
Tab. 3. Occurrence of geriatric syndromes combinations according to age and sex.

\begin{tabular}{|c|c|c|c|c|c|c|c|c|c|c|c|c|}
\hline \multirow[t]{2}{*}{ Falls } & \multirow[t]{2}{*}{ Immobility } & \multirow[t]{2}{*}{ Incontinence } & \multirow[t]{2}{*}{ Dementia } & \multirow[t]{2}{*}{ Total } & \multicolumn{3}{|c|}{ Female } & \multirow{2}{*}{$\begin{array}{c}\text { Total } \\
\text { Females }\end{array}$} & \multicolumn{3}{|c|}{ Male } & \multirow{2}{*}{$\begin{array}{l}\text { Total } \\
\text { Males }\end{array}$} \\
\hline & & & & & $65-74$ yrs & $75-84$ yrs & $\geq 85 \mathrm{yrs}$ & & $65-74$ yrs & $75-84$ yrs & $\geq 85 \mathrm{yrs}$ & \\
\hline Yes & Yes & Yes & Yes & $\begin{array}{c}814 \\
(6.7 \%) \\
\end{array}$ & $\begin{array}{c}43 \\
(2.8 \%) \\
\end{array}$ & $\begin{array}{c}201 \\
(5.2 \%) \\
\end{array}$ & $\begin{array}{c}343 \\
(12.5 \%) \\
\end{array}$ & $\begin{array}{c}587 \\
(7.2 \%) \\
\end{array}$ & $\begin{array}{c}24 \\
(2.2 \%) \\
\end{array}$ & $\begin{array}{c}101 \\
(5.1 \%) \\
\end{array}$ & $\begin{array}{c}102 \\
(10.2 \%) \\
\end{array}$ & $\begin{array}{c}227 \\
(5.6 \%) \\
\end{array}$ \\
\hline Yes & Yes & Yes & No & $\begin{array}{c}628 \\
(5.1 \%) \\
\end{array}$ & $\begin{array}{c}57 \\
(3.8 \%) \\
\end{array}$ & $\begin{array}{c}170 \\
(4.4 \%) \\
\end{array}$ & $\begin{array}{c}203 \\
(7.4 \%) \\
\end{array}$ & $\begin{array}{c}430 \\
(5.3 \%) \\
\end{array}$ & $\begin{array}{c}34 \\
(3.1 \%) \\
\end{array}$ & $\begin{array}{c}100 \\
(5.1 \%) \\
\end{array}$ & $\begin{array}{c}64 \\
(6.4 \%) \\
\end{array}$ & $\begin{array}{c}198 \\
(4.9 \%) \\
\end{array}$ \\
\hline Yes & Yes & No & Yes & $\begin{array}{c}38 \\
(0.3 \%)\end{array}$ & $\begin{array}{c}2 \\
(0.1 \%)\end{array}$ & $\begin{array}{c}9 \\
(0.2 \%)\end{array}$ & $\begin{array}{c}17 \\
(0.6 \%)\end{array}$ & $\begin{array}{c}28 \\
(0.3 \%)\end{array}$ & $\begin{array}{c}3 \\
(0.3 \%) \\
\end{array}$ & $\begin{array}{c}2 \\
(0.1 \%)\end{array}$ & $\begin{array}{c}5 \\
(0.5 \%)\end{array}$ & $\begin{array}{c}10 \\
(0.2 \%)\end{array}$ \\
\hline Yes & Yes & No & No & $\begin{array}{c}124 \\
(1.0 \%) \\
\end{array}$ & $\begin{array}{c}15 \\
(1.0 \%) \\
\end{array}$ & $\begin{array}{c}36 \\
(1.0 \%) \\
\end{array}$ & $\begin{array}{c}31 \\
(1.1 \%) \\
\end{array}$ & $\begin{array}{c}82 \\
(1.0 \%) \\
\end{array}$ & $\begin{array}{c}12 \\
(1.1 \%) \\
\end{array}$ & $\begin{array}{c}19 \\
(1.0 \%) \\
\end{array}$ & $\begin{array}{c}11 \\
(1.1 \%)\end{array}$ & $\begin{array}{c}42 \\
(1.0 \%) \\
\end{array}$ \\
\hline Yes & No & Yes & Yes & $\begin{array}{c}733 \\
(6.0 \%) \\
\end{array}$ & $\begin{array}{c}47 \\
(3.1 \%) \\
\end{array}$ & $\begin{array}{c}221 \\
(5.7 \%) \\
\end{array}$ & $\begin{array}{c}217 \\
(7.9 \%) \\
\end{array}$ & $\begin{array}{c}485 \\
(6.0 \%) \\
\end{array}$ & $\begin{array}{c}50 \\
(4.5 \%) \\
\end{array}$ & $\begin{array}{c}115 \\
(5.8 \%) \\
\end{array}$ & $\begin{array}{c}83 \\
(8.3 \%) \\
\end{array}$ & $\begin{array}{c}248 \\
(6.1 \%) \\
\end{array}$ \\
\hline Yes & No & Yes & No & $\begin{array}{c}1358 \\
(11.1 \%) \\
\end{array}$ & $\begin{array}{c}170 \\
(11.2 \%) \\
\end{array}$ & $\begin{array}{c}413 \\
(10.7 \%) \\
\end{array}$ & $\begin{array}{c}313 \\
(11.4 \%) \\
\end{array}$ & $\begin{array}{c}896 \\
(11.0 \%) \\
\end{array}$ & $\begin{array}{c}151 \\
(13.7 \%) \\
\end{array}$ & $\begin{array}{c}203 \\
(10.3 \%)\end{array}$ & $\begin{array}{c}108 \\
(10.8 \%)\end{array}$ & $\begin{array}{c}462 \\
(11.3 \%)\end{array}$ \\
\hline Yes & No & No & Yes & $\begin{array}{c}46 \\
(0.4 \%) \\
\end{array}$ & $\begin{array}{c}4 \\
(0.3 \%) \\
\end{array}$ & $\begin{array}{c}12 \\
(0.3 \%) \\
\end{array}$ & $\begin{array}{c}14 \\
(0.5 \%) \\
\end{array}$ & $\begin{array}{c}30 \\
(0.4 \%) \\
\end{array}$ & $\begin{array}{c}3 \\
(0.3 \%) \\
\end{array}$ & $\begin{array}{c}12 \\
(0.6 \%) \\
\end{array}$ & $\begin{array}{c}1 \\
(0.1 \%) \\
\end{array}$ & $\begin{array}{c}16 \\
(0.4 \%) \\
\end{array}$ \\
\hline Yes & No & No & No & $\begin{array}{c}284 \\
(2.3 \%) \\
\end{array}$ & $\begin{array}{c}61 \\
(4.0 \%) \\
\end{array}$ & $\begin{array}{c}75 \\
(2.0 \%) \\
\end{array}$ & $\begin{array}{c}30 \\
(1.1 \%) \\
\end{array}$ & $\begin{array}{c}166 \\
(2.0 \%) \\
\end{array}$ & $\begin{array}{c}57 \\
(5.2 \%) \\
\end{array}$ & $\begin{array}{c}41 \\
(2.1 \%) \\
\end{array}$ & $\begin{array}{c}20 \\
(2.0 \%) \\
\end{array}$ & $\begin{array}{c}118 \\
(2.9 \%) \\
\end{array}$ \\
\hline No & Yes & Yes & Yes & $\begin{array}{c}733 \\
(6.0 \%) \\
\end{array}$ & $\begin{array}{c}42 \\
(2.8 \%)\end{array}$ & $\begin{array}{c}213 \\
(5.5 \%) \\
\end{array}$ & $\begin{array}{c}246 \\
(9.0 \%)\end{array}$ & $\begin{array}{c}501 \\
(6.2 \%)\end{array}$ & $\begin{array}{c}38 \\
(3.5 \%)\end{array}$ & $\begin{array}{c}118 \\
(6.0 \%)\end{array}$ & $\begin{array}{c}76 \\
(7.6 \%) \\
\end{array}$ & $\begin{array}{c}232 \\
(5.7 \%) \\
\end{array}$ \\
\hline No & Yes & Yes & No & $\begin{array}{c}822 \\
(6.7 \%) \\
\end{array}$ & $\begin{array}{c}73 \\
(4.8 \%) \\
\end{array}$ & $\begin{array}{c}270 \\
(7.0 \%) \\
\end{array}$ & $\begin{array}{c}247 \\
(9.0 \%) \\
\end{array}$ & $\begin{array}{c}590 \\
(7.3 \%) \\
\end{array}$ & $\begin{array}{c}44 \\
(4.0 \%) \\
\end{array}$ & $\begin{array}{c}114 \\
(5.8 \%) \\
\end{array}$ & $\begin{array}{c}74 \\
(7.4 \%) \\
\end{array}$ & $\begin{array}{c}232 \\
(5.7 \%) \\
\end{array}$ \\
\hline No & Yes & No & Yes & $\begin{array}{c}231 \\
(1.9 \%)\end{array}$ & $\begin{array}{c}10 \\
(0.7 \%)\end{array}$ & $\begin{array}{c}76 \\
(2.0 \%)\end{array}$ & $\begin{array}{c}71 \\
(2.6 \%) \\
\end{array}$ & $\begin{array}{c}157 \\
(1.9 \%)\end{array}$ & $\begin{array}{c}15 \\
(1.4 \%)\end{array}$ & $\begin{array}{c}38 \\
(1.9 \%)\end{array}$ & $\begin{array}{c}21 \\
(2.1 \%)\end{array}$ & $\begin{array}{c}74 \\
(1.8 \%)\end{array}$ \\
\hline No & Yes & No & No & $\begin{array}{c}1012 \\
(8.3 \%) \\
\end{array}$ & $\begin{array}{c}136 \\
(9.0 \%) \\
\end{array}$ & $\begin{array}{c}356 \\
(9.2 \%) \\
\end{array}$ & $\begin{array}{c}194 \\
(7.1 \%) \\
\end{array}$ & $\begin{array}{c}686 \\
(8.4 \%) \\
\end{array}$ & $\begin{array}{c}91 \\
(8.3 \%) \\
\end{array}$ & $\begin{array}{c}159 \\
(8.1 \%) \\
\end{array}$ & $\begin{array}{c}76 \\
(7.6 \%) \\
\end{array}$ & $\begin{array}{c}326 \\
(8.0 \%) \\
\end{array}$ \\
\hline No & No & Yes & Yes & $\begin{array}{c}281 \\
(2.3 \%) \\
\end{array}$ & $\begin{array}{c}23 \\
(1.5 \%) \\
\end{array}$ & $\begin{array}{c}95 \\
(2.5 \%) \\
\end{array}$ & $\begin{array}{c}88 \\
(3.2 \%) \\
\end{array}$ & $\begin{array}{c}206 \\
(2.5 \%) \\
\end{array}$ & $\begin{array}{c}13 \\
(1.2 \%) \\
\end{array}$ & $\begin{array}{c}40 \\
(2.0 \%)\end{array}$ & $\begin{array}{c}22 \\
(2.2 \%)\end{array}$ & $\begin{array}{c}75 \\
(1.8 \%)\end{array}$ \\
\hline No & No & Yes & No & $\begin{array}{c}1,055 \\
(8.6 \%) \\
\end{array}$ & $\begin{array}{c}125 \\
(8.3 \%) \\
\end{array}$ & $\begin{array}{c}379 \\
(9.8 \%) \\
\end{array}$ & $\begin{array}{c}251 \\
(9.1 \%) \\
\end{array}$ & $\begin{array}{c}755 \\
(9.3 \%) \\
\end{array}$ & $\begin{array}{c}67 \\
(6.1 \%) \\
\end{array}$ & $\begin{array}{c}142 \\
(7.2 \%) \\
\end{array}$ & $\begin{array}{c}91 \\
(9.1 \%) \\
\end{array}$ & $\begin{array}{c}300 \\
(7.4 \%) \\
\end{array}$ \\
\hline No & No & No & Yes & $\begin{array}{c}264 \\
(2.2 \%)\end{array}$ & $\begin{array}{c}32 \\
(2.1 \%)\end{array}$ & $\begin{array}{c}79 \\
(2.0 \%)\end{array}$ & $\begin{array}{c}50 \\
(1.8 \%)\end{array}$ & $\begin{array}{c}161 \\
(2.0 \%)\end{array}$ & $\begin{array}{c}28 \\
(2.5 \%)\end{array}$ & $\begin{array}{c}52 \\
(2.6 \%)\end{array}$ & $\begin{array}{c}23 \\
(2.3 \%)\end{array}$ & $\begin{array}{c}103 \\
(2.5 \%)\end{array}$ \\
\hline No & No & No & No & $\begin{array}{c}3,787 \\
(31.0 \%)\end{array}$ & $\begin{array}{c}672 \\
44.4 \%)\end{array}$ & $\begin{array}{c}1271 \\
(32.8 \%)\end{array}$ & $\begin{array}{c}431 \\
(15.7 \%)\end{array}$ & $\begin{array}{c}2374 \\
(29.2 \%)\end{array}$ & $\begin{array}{c}473 \\
(42.9 \%)\end{array}$ & $\begin{array}{c}713 \\
(36.2 \%)\end{array}$ & $\begin{array}{c}227 \\
(22.6 \%)\end{array}$ & $\begin{array}{c}1413 \\
(34.7 \%)\end{array}$ \\
\hline
\end{tabular}

for various syndromes or their combinations was reported (male and female patients have been analysed separately and mutually compared). The age cut-offs have been defined according to the highest sum of sensitivity and specificity for given age. Logistic regression was adopted for the analysis of relationship between gender, age and occurrence of geriatric syndromes. Odd ratios were used to describe this relationship.

The analysis has been performed in SPSS 18.0.3 (IBM Corporation, 2010) and $\alpha=0.05$ has been used as a level of statistical significance for all statistical tests.

\section{Results}

Table 2 presents the occurrence of GS in relation to age categories and sex. All the syndromes were found to be statistically significantly dependent on age. With the exception of dependency at discharge and malnutrition at least some difference between sexes was found for all the syndromes. This difference between sexes is especially apparent for loneliness, need of aftercare, nursing home admission, and incontinency; in all the cases the syndromes have higher occurrence in women.

Table 3 describes the occurrence of main geriatric syndrome combinations in relation to age and sex.
Figure 1 shows the relationship between main geriatric syndromes occurrence and age in a graphical form together with statistical significance of the difference between sexes within age categories. The dependence of the appearance of all GS on age is unambiguous for both men and women. At least for some age categories, all the syndromes are more common in women of higher age; if some syndromes are more common in men it is the youngest age category that they occur in (incontinency below 65 $\mathrm{y}$ or dementia in 66-70 y category).

Table 4 depicts mobility in relation to age and sex. Patients are divided to four subsets, namely fully mobile, mobile with help, on wheelchair, and immobile. These results confirm the relationship between the increasing occurrence of various degrees of limited mobility and increasing age. The differences between men and women start occurring beginning with the 75 th year of age when women become less mobile than men.

Table 5 presents the results of ROC analysis between age and occurrence of syndromes. Although all the results are statistically significant, the predictive power for age is relatively low (all AUCs below 0.75); nevertheless it provides some information on age cut-offs when the syndromes can be expected with higher probability. The age cut-offs are defined according to the highest sum of sensitivity and specificity for given age. Except for im- 

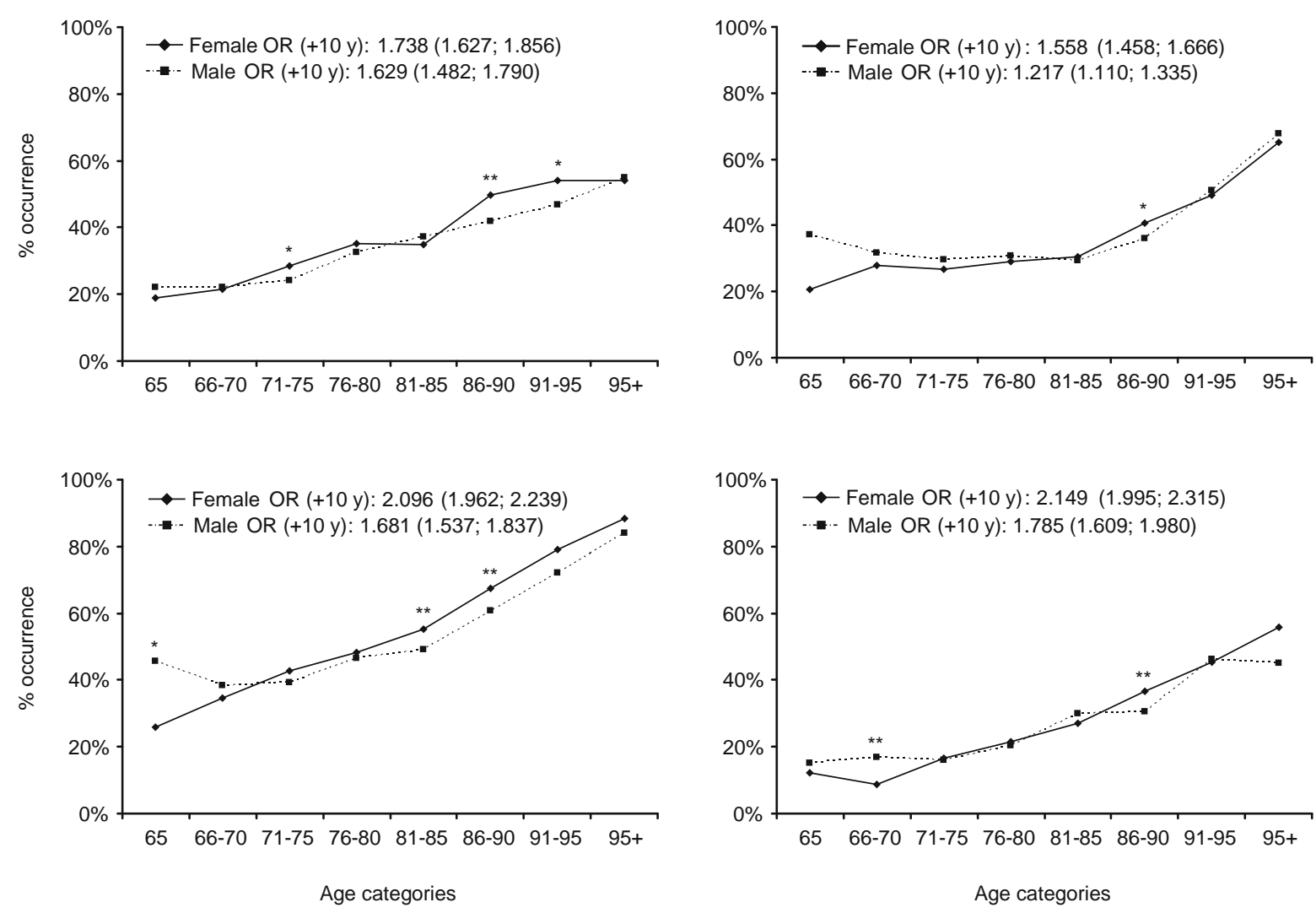

Fig. 1. Relationship between geriatric syndromes occurrence and age. Significant difference between males and females (Fisher exact test) * $\mathbf{p}<\mathbf{0 . 0 5}, * * \mathbf{p}<\mathbf{0 . 0 1}$. Statistical significance of gender and age as overall predictors of syndromes is based on logistic regression. $\mathrm{OR}=\mathbf{o d d s}-$ ratio from the logistic regression for age change by 10 years; it shows how many times higher the odds for having given syndrome are when age changes by 10 years.

Tab. 4. Mobility according to age and sex.

\begin{tabular}{|c|c|c|c|}
\hline & Female & Male & $\mathrm{p}^{1}$ \\
\hline $\begin{array}{l}\text { Fully mobile } \\
65-74 \mathrm{yrs} \\
75-84 \mathrm{yrs} \\
\geq 85 \mathrm{yrs} \\
\mathrm{p}^{2}\end{array}$ & $\begin{array}{c}740(48.9 \%) \\
1,600(41.3 \%) \\
676(24.6 \%) \\
<0.001\end{array}$ & $\begin{array}{c}253(22.9 \%) \\
869(44.1 \%) \\
323(32.2 \%) \\
<0.001\end{array}$ & $\begin{array}{c}0.452 \\
0.038 \\
<0.001\end{array}$ \\
\hline $\begin{array}{l}\text { With help } \\
65-74 \text { yrs } \\
75-84 \text { yrs } \\
\geq 85 \text { yrs } \\
\mathrm{p}^{2}\end{array}$ & $\begin{array}{c}373(24.7 \%) \\
1,139(29.4 \%) \\
902(32.9 \%) \\
<0.001\end{array}$ & $\begin{array}{c}246(22.3 \%) \\
507(25.8 \%) \\
284(28.3 \%) \\
0.001\end{array}$ & $\begin{array}{l}0.163 \\
0.003 \\
0.014\end{array}$ \\
\hline $\begin{array}{l}\text { On wheelchair } \\
65-74 \text { yrs } \\
75-84 \text { yrs } \\
\geq 85 \text { yrs } \\
\text { p }^{2}\end{array}$ & $\begin{array}{c}181(12.0 \%) \\
442(11.4 \%) \\
440(16.0 \%) \\
<0.001\end{array}$ & $\begin{array}{c}142(12.9 \%) \\
222(11.3 \%) \\
133(13.3 \%) \\
0.858\end{array}$ & $\begin{array}{l}0.508 \\
0.896 \\
0.040\end{array}$ \\
\hline $\begin{array}{l}\text { Immobile } \\
65-74 \text { yrs } \\
75-84 \text { yrs } \\
\geq 85 \text { yrs } \\
p^{2}\end{array}$ & $\begin{array}{c}218(14.4 \%) \\
695(17.9 \%) \\
728(26.5 \%) \\
<0.001\end{array}$ & $\begin{array}{c}192(17.4 \%) \\
371(18.8 \%) \\
261(26.0 \%) \\
<0.001\end{array}$ & $\begin{array}{l}0.039 \\
0.410 \\
0.770\end{array}$ \\
\hline
\end{tabular}

${ }^{1}$ Statistical significance of difference between men/women within given age group was assessed by Fisher exact test

${ }^{2}$ Statistical significance of difference among age groups within men/women assessed by Kendall tau test mobility, all GS appearing either individually or in combinations take place earlier in males. Age cut-off for geriatric syndromes occurrence based on ROC analysis is $83.5-84.5 \mathrm{y}$ for females and $78.5-82.5$ y for males.

Figure 2 is a graphical depiction of the relationship between the occurrences of geriatric syndromes and age of their appearance according to sex. It was confirmed that the relationship between age and number of syndromes was statistically significant. The older female categories were found to have higher occurrence of at least two or three syndromes.

Table 6 shows the results of ROC analysis for the combination of main syndromes in patients. Again, all the AUCs are below or around 0.75 , thus indicating low discrimination power and providing only tentative age cut-offs for the occurrence of syndrome combinations.

Figure 3 presents the relationship between other syndrome occurrences as to age and gender according to loneliness (Fig. 3a), need of aftercare, nursing home admission, dependency, and malnutrition (Fig. 3b-f). All syndromes indicate a dependency growing with age. Loneliness is highly significantly more frequent in women than in men within all age groups with the exception of the youngest and oldest patients. Aftercare, nursing, and dependency at admission are more frequent in older women. Dependency at discharge and malnutrition show no statistically significant differences between sexes. 
408-416

Tab. 5. Age cut-off for geriatric syndromes based on ROC analysis.

\begin{tabular}{|c|c|c|c|c|c|c|}
\hline & Sex & $\mathrm{AUC}^{1}$ & $\mathrm{p}^{1}$ & Cut-off $^{2}$ & Sensitivity $^{2}$ & Specificity $^{2}$ \\
\hline \multirow[t]{2}{*}{ Falls } & Female & 0.608 & $<0.001$ & $84.5 \mathrm{yrs}$ & $44.2 \%$ & $72.5 \%$ \\
\hline & Male & 0.599 & $<0.001$ & $78.5 \mathrm{yrs}$ & $64.9 \%$ & $51.1 \%$ \\
\hline \multirow[t]{2}{*}{ Immobility } & Female & 0.586 & $<0.001$ & $84.5 \mathrm{yrs}$ & $43.2 \%$ & $70.9 \%$ \\
\hline & Male & 0.537 & $<0.001$ & $84.5 \mathrm{yrs}$ & $29.8 \%$ & $77.9 \%$ \\
\hline \multirow[t]{2}{*}{ Incontinency } & Female & 0.642 & $<0.001$ & $83.5 \mathrm{yrs}$ & $47.8 \%$ & $72.3 \%$ \\
\hline & Male & 0.599 & $<0.001$ & $82.5 \mathrm{yrs}$ & $41.1 \%$ & $72.6 \%$ \\
\hline \multirow[t]{2}{*}{ Dementia } & Female & 0.646 & $<0.001$ & $83.5 \mathrm{yrs}$ & $54.3 \%$ & $66.9 \%$ \\
\hline & Male & 0.616 & $<0.001$ & $80.5 \mathrm{yrs}$ & $58.2 \%$ & $60.7 \%$ \\
\hline \multirow[t]{2}{*}{ Loneliness } & Female & 0.629 & $<0.001$ & 80.5 yrs & $59.0 \%$ & $60.2 \%$ \\
\hline & Male & 0.594 & $<0.001$ & $80.5 \mathrm{yrs}$ & $51.4 \%$ & $62.6 \%$ \\
\hline \multirow[t]{2}{*}{ Aftercare } & Female & 0.561 & $<0.001$ & $84.5 \mathrm{yrs}$ & $41.2 \%$ & $68.1 \%$ \\
\hline & Male & 0.548 & $<0.001$ & $80.5 \mathrm{yrs}$ & $49.6 \%$ & $57.3 \%$ \\
\hline \multirow[t]{2}{*}{ Nursing home admission } & Female & 0.646 & $<0.001$ & $83.5 \mathrm{yrs}$ & $59.8 \%$ & $62.2 \%$ \\
\hline & Male & 0.584 & 0.003 & $83.5 \mathrm{yrs}$ & $44.3 \%$ & $71.1 \%$ \\
\hline Dependency - admission & Male & 0.560 & $<0.001$ & $85.5 \mathrm{yrs}$ & $25.7 \%$ & $84.2 \%$ \\
\hline \multirow[t]{2}{*}{ Dependency -discharge } & Female & 0.597 & $<0.001$ & $84.5 \mathrm{yrs}$ & $43.4 \%$ & $72.0 \%$ \\
\hline & Male & 0.563 & $<0.001$ & $85.5 \mathrm{yrs}$ & $27.4 \%$ & $83.3 \%$ \\
\hline \multirow[t]{2}{*}{ At least 1 syndrome } & Female & 0.653 & $<0.001$ & $84.5 \mathrm{yrs}$ & $40.2 \%$ & $81.8 \%$ \\
\hline & Male & 0.597 & $<0.001$ & $79.5 \mathrm{yrs}$ & $54.3 \%$ & $61.1 \%$ \\
\hline \multirow[t]{2}{*}{ At least 2 syndromes } & Female & 0.649 & $<0.001$ & $84.5 \mathrm{yrs}$ & $44.8 \%$ & $76.9 \%$ \\
\hline & Male & 0.593 & $<0.001$ & 78.5 yrs & $61.4 \%$ & $51.7 \%$ \\
\hline \multirow[t]{2}{*}{ At least 3 syndromes } & Female & 0.650 & $<0.001$ & $84.5 \mathrm{yrs}$ & $50.5 \%$ & $71.8 \%$ \\
\hline & Male & 0.626 & $<0.001$ & 80.5 yrs & $58.3 \%$ & $60.3 \%$ \\
\hline \multirow[t]{2}{*}{ All syndromes } & Female & 0.664 & $<0.001$ & $84.5 \mathrm{yrs}$ & $58.4 \%$ & $68.2 \%$ \\
\hline & Male & 0.674 & $<0.001$ & $82.5 \mathrm{yrs}$ & $57.3 \%$ & $67.3 \%$ \\
\hline
\end{tabular}

${ }^{1}$ area under curve based on ROC analyses (range 0.5-1.0; higher value means better discrimination power) and its statistical significance for occurrence of syndrome in relationship to age within given sex group

${ }^{2}$ optimal cut-off for age and sensitivity and specificity at this cut-off

\section{Discussion}

Our long-term experience with multi-morbid old patients leads us to a conclusion that once the senior has been detected as acutely ill and once the therapy has been introduced after admission to acute geriatric ward, it is desirable to consider carefully all further comorbidities, and any other additional treatment, especially regarding drug interactions and side effects. Continuous assessment of patient's self-sufficiency and mental status is of crucial significance in the ageing patients.

Falls represent a complex multifactorial phenomenon which could be caused by several risk factors $(11,12,13)$. Lakhan (10) depicts minimally one fall that took place 90 days before admission to the hospital in $41.9 \%$ of people at the age of $70 \mathrm{y}$. Billington (14) indicates risk factors for falls in hospitalized patients, namely gait instability, mental disorders, urge incontinence, past history of falling, use of psychopharmaceuticals, restraints, and environmental factors. The number of risk factors increases the predisposition for falls (4.15). The occurrence of falls in our patient set is showed in Table 2 and Figure 1. The increase in the tendency towards falling increasing with age is statistically significant for both genders. The prevalence of falls as to sex is comparable except for age ranges of 71-75 and 85-95 y where the females fall more frequently (Fig. 1) (in $39.5 \%$ of females vs. $36.1 \%$ of males).

Falls are a frequent cause of morbidity and mortality generally in the elderly and in people suffering from dementia or cog- nitive impairment with a two to three times higher risk of falling compared with a cognitively healthy person (16-20). Gillespie (21) depicts significant protection against falling apparent from interventions which targeted multiple identified risk factors in individual patients. Some authors emphasize positive effects of physical activity in the prevention of falls (22-24). The intervention against falling must be complex $(24,25)$ and target both environmental and intrinsic risk factors of individual patients (21), as well as polypharmacy reduction (26). The risk of falling increases with age and the declining muscle function reduces the ability to get up (27). Moncada (28) emphasizes multifactorial intervention as an effective means for decreasing the falls, namely by exercise and gait training, modification of home environment, minimization of medication, and management of postural hypotension, foot problems and footwear.

Mobility is one of the most important factors for the well-being and autonomy in old age (29). Impairments in mobility, falls and fear of falling $(30,31)$ are therefore of prognostic value (32). Impaired mobility in the elderly, frequent falls and poor balance are connected with the increase in sarcopenia $(33,34)$. In our set we found a correlation between age and mobility problems (Tab. 2, Fig. 1b). Table 4 analyses the mobility disorders according to age and sex. The occurrence of fully immobile persons of both genders is nearly doubled when we compare young-old and the "oldest-of-old" groups of seniors. Jacobs (35) describes a similar doubling as we do. Similarly to Fleming (27), we found immobil- 

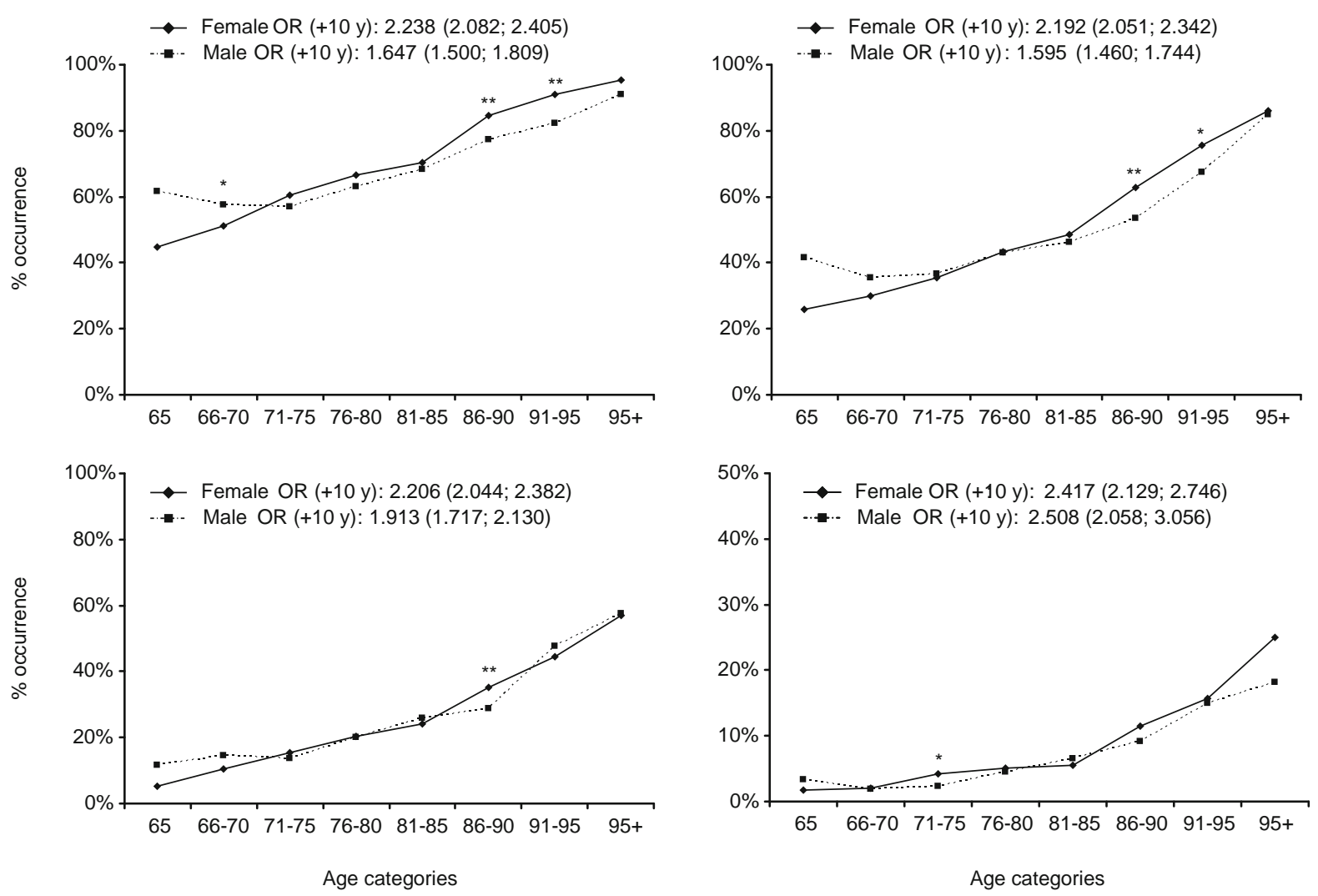

Fig. 2. Relationship between number of geriatric syndromes occurrence and age. Significant difference between male and females (Fisher exact test) $* \mathbf{p}<0.05,{ }^{* *} \mathbf{p}<0.01$. Statistical significance of gender and age as overall predictors of syndromes is based on logistic regression. OR = odds-ratio from the logistic regression for age change by 10 years; it shows how many times higher the odds for having given syndrome are when age changes by 10 years.

ity altogether at admission time in the "oldest-of-old" group to be present in $42.5 \%$ of females and $39.2 \%$ of males (Tab. 2). In the set of acutely admitted patients of mean age of $85.8 \mathrm{y}$, RodriguezPascal (36) indicates that $66 \%$ had mobility problems and $50 \%$ of them required help with activities of daily living. Both ADL decrease and mobility disorders result in diminished survival. Mobility disorders are often associated with falls, dementia and disability $(37,38)$. Our results (Tab. 2b) emphasize high sensitivity and specificity of the simultaneous presence of falls and dementia.

Prevalence of incontinency was in both genders of our set higher in comparison to other authors. The possible explanation could lie in a serious somatic status in general. Also the increase with age and higher occurrence among the females in the group of 75-84 y and $85+y$ are obvious. The prevalence and severity of urinary incontinence (UI) symptoms increase with age and have a considerably negative influence on the quality of life (39, 40). Wehrberger (39) describes UI in $85+$ community of dwelling persons to occur in $24 \%$ of men and $35 \%$ of women. Goode (41) also depicts UI prevalence in a community of dwelling seniors however in a slightly younger set as occurring in $41 \%$ of women and $27 \%$ of men. Similarly to our findings (Fig. 1c), Milsom (42) found a linear dependency between the prevalence of UI and age for a female cohort. Lakhan (10) presents bladder incontinency in $70+\mathrm{y}$ acutely admitted persons in $36.7 \%$. We are in agreement with Hampel (43) that additional risk factors for male UI are age, immobility (Tab. 3, Fig. 2), and neurological diseases. In the view of recent data on prevalence of UI in women ranging from 5 to 69 $\%$ (44), with most studies the reported prevalence of any urinary incontinence is in the range of $25-45 \%$. This is essentially in agreement with our results (Tab. 2). Jacobs (35) depicts UI in 42.5 $\%$ among "oldest-of-old" in a community of dwelling persons.

Psychiatric disorders in the elderly are often related to cerebral neurodegeneration and cerebrovascular disease and combined with GS (45). In our study, the prevalence of any GS (Figs 1 and 2) was higher among females $85+\mathrm{y}$, both singularly and in combinations. Practically all GS were more prevalent in the group of females aged $85+\mathrm{y}$, especially in the subgroup of those aged 86-90 y.

Psychiatric disorders, common among the elderly, have consequences that include social deprivation, poor quality of life, cognitive decline, disability, increased risk of somatic disorders, suicide, and increased non-suicidal mortality $(46,47)$. The prevalence of both Alzheimer's disease (AD) and vascular dementia (VaD) increase with advancing age, but epidemiologic data in literature dealing with age over 85 are imprecise and inconsistent (47-49). 
408-416

Tab. 6. Age cut-off for combination of main geriatric syndromes based on ROC analysis.

\begin{tabular}{|c|c|c|c|c|c|c|}
\hline Combination of main geriatric syndromes $^{1}$ & Sex & $\mathrm{AUC}^{2}$ & $\mathrm{p}^{2}$ & Cut-off $^{3}$ & Sensitivity $^{3}$ & Specificity $^{3}$ \\
\hline \multirow{2}{*}{ Dementia only $(n=264)$} & Female & 0.609 & $<0.001$ & $\geq 79.5$ & $65.2 \%$ & $53.4 \%$ \\
\hline & Male & 0.556 & 0.058 & $\geq 78.5$ & $58.3 \%$ & $55.7 \%$ \\
\hline \multirow[t]{2}{*}{ Immobility only $(\mathrm{n}=284)$} & Female & 0.544 & 0.059 & $\leq 73.5$ & $33.1 \%$ & $76.6 \%$ \\
\hline & Male & 0.57 & 0.011 & $\leq 75.5$ & $54.2 \%$ & $61.0 \%$ \\
\hline \multirow[t]{2}{*}{ Falls only $(n=1012)$} & Female & 0.573 & $<0.001$ & $\geq 85.5$ & $24.3 \%$ & $87.0 \%$ \\
\hline & Male & 0.567 & $<0.001$ & $\geq 79.5$ & $52.8 \%$ & $61.1 \%$ \\
\hline \multirow[t]{2}{*}{ Incontinency only $(\mathrm{n}=1055)$} & Female & 0.617 & $<0.001$ & $\geq 81.5$ & $52.1 \%$ & $65.2 \%$ \\
\hline & Male & 0.604 & $<0.001$ & $\geq 79.5$ & $54.7 \%$ & $61.1 \%$ \\
\hline \multirow[t]{2}{*}{ Immobility\&Dementia $(\mathrm{n}=46)$} & Female & 0.664 & 0.002 & $\geq 84.5$ & $46.7 \%$ & $81.8 \%$ \\
\hline & Male & 0.562 & 0.391 & $\geq 77.5$ & $68.8 \%$ & $50.0 \%$ \\
\hline \multirow[t]{2}{*}{ Falls\&Immobility $(\mathrm{n}=124)$} & Female & 0.610 & 0.001 & $\geq 84.5$ & $37.8 \%$ & $81.8 \%$ \\
\hline & Male & 0.554 & 0.233 & $\geq 77.5$ & $61.9 \%$ & $50.0 \%$ \\
\hline \multirow[t]{2}{*}{ Falls\&Dementia $(n=231)$} & Female & 0.712 & $<0.001$ & $\geq 81.5$ & $65.6 \%$ & $65.2 \%$ \\
\hline & Male & 0.620 & $<0.001$ & $\geq 78.5$ & $63.5 \%$ & $55.7 \%$ \\
\hline \multirow{2}{*}{ Incontinency\&Dementia $(\mathrm{n}=281)$} & Female & 0.701 & $<0.001$ & $\geq 82.5$ & $60.2 \%$ & $70.7 \%$ \\
\hline & Male & 0.631 & $<0.001$ & $\geq 80.5$ & $58.7 \%$ & $65.5 \%$ \\
\hline \multirow[t]{2}{*}{ Falls\&Incontinency $(\mathrm{n}=822)$} & Female & 0.669 & $<0.001$ & $\geq 84.5$ & $41.9 \%$ & $81.8 \%$ \\
\hline & Male & 0.634 & $<0.001$ & $\geq 78.5$ & $66.4 \%$ & $55.7 \%$ \\
\hline \multirow[t]{2}{*}{ Immobility\&Incontinency $(\mathrm{n}=1358)$} & Female & 0.610 & $<0.001$ & $\geq 84.5$ & $34.9 \%$ & $81.8 \%$ \\
\hline & Male & 0.518 & 0.242 & $\geq 84.5$ & $23.4 \%$ & $83.9 \%$ \\
\hline \multirow[t]{2}{*}{ Falls\&Immobility\&Dementia $(n=38)$} & Female & 0.769 & $<0.001$ & $\geq 85.5$ & $57.1 \%$ & $87.0 \%$ \\
\hline & Male & 0.658 & 0.085 & $\geq 86.5$ & $50.0 \%$ & $90.3 \%$ \\
\hline \multirow[t]{2}{*}{ Falls\&Immobility\&Incontinency $(\mathrm{n}=628)$} & Female & 0.681 & $<0.001$ & $\geq 84.5$ & $47.2 \%$ & $81.8 \%$ \\
\hline & Male & 0.616 & $<0.001$ & $\geq 75.5$ & $77.3 \%$ & $39.0 \%$ \\
\hline \multirow[t]{2}{*}{ Immobility\&Incontinency\&Dementia $(\mathrm{n}=733)$} & Female & 0.707 & $<0.001$ & $\geq 82.5$ & $57.7 \%$ & $70.7 \%$ \\
\hline & Male & 0.638 & $<0.001$ & $\geq 80.5$ & $57.3 \%$ & $65.5 \%$ \\
\hline \multirow[t]{2}{*}{ Falls\&Incontinency\&Dementia $(\mathrm{n}=733)$} & Female & 0.719 & $<0.001$ & $\geq 83.5$ & $54.5 \%$ & $76.4 \%$ \\
\hline & Male & 0.658 & $<0.001$ & $\geq 79.5$ & $67.2 \%$ & $61.1 \%$ \\
\hline \multirow{2}{*}{ Falls\&Immobility\&Incontinency\&Dementia $(\mathrm{n}=814)$} & Female & 0.752 & $<0.001$ & $\geq 84.5$ & $58.4 \%$ & $81.8 \%$ \\
\hline & Male & 0.726 & $<0.001$ & $\geq 80.5$ & $67.0 \%$ & $65.5 \%$ \\
\hline
\end{tabular}

${ }^{1}$ reference category are patients without any main geriatric syndrome $(\mathrm{N}=3787)$

${ }^{2}$ area under curve based on ROC analyses (range 0.5-1.0; higher value means better discrimination power) and its statistical significance for occurrence of combination of main syndromes in relationship to age within given sex group

${ }^{3}$ optimal cut-off for age and sensitivity and specificity at this cut-off

Jellinger (48) describes a growing tendency in the prevalence of dementia, and after the age of 90 this tendency shows a considerably slight diminution. We observed the same phenomenon (Fig. 1d) but only in males, not in females. We found cognitive impairment or dementia signs generally in $38.1 \%$ of females and in 33.2 $\%$ of males in the "oldest-of-old" set of patients $(\geq 85 \mathrm{y})$. Other authors $(35,36)$ depict cognitive impairment in $40-45 \%$ of the "oldest-of-old" persons. Lakhan (10) found cognitive impairment in $34.3 \%$ of $70+y$ persons.

We observed a significant increase in geriatric syndromes occurrence (Fig. 2) with increasing age, particularly for the "oldestof-old" group $(85+y)$. The growth is especially obvious for simultaneous presence of two or more GS for the subset $\geq 85 \mathrm{y}$. We also found a rise in the need of aftercare and nursing home admission (Tab. 2) and dependency at the time of admission and discharge assessed by ADL test was found to grow with age and namely worse for females. Jacobs (35) emphasizes that at age of 70, the overall health profile was favourable, prevalence of GS was low, cognitive and functional status was preserved, and health service utilization was low. The progressive deterioration seen at the age over 78 and profoundly at age 85 suggests that a cut-off point beyond the age of 70 may serve as a better age point defining the entry into old age.
Malnutrition and impaired homeostasis exerted twice the influence of factors such as multiple comorbidities and frailty (50-52). We observed a significant increase in malnutrition with ageing (Fig. 3f) with no dependency on gender. Geriatric syndrome information is helpful for understanding the survival in younger old persons but provides little knowledge about survival in the very old.

\section{Conclusion}

Our study gives useful epidemiological information and longterm experience with the prevalence of common GS as from admission to the acute geriatric department. This study suggests that there is a need of better configuration of acute medical departments admitting acutely ill elderly people.

\section{References}

1. Halter J, Ouslander J, Tinetti M, Studenski S, High K, Asthana S. Hazzard's Geriatric Medicine and Gerontology (Principles of Geriatric Medicine \& Gerontology). New York: McGraw-Hill Professional, 2009.

2. RaiGurcharan S, Mulley GP (Eds). Elderly medicine : a training guide. Edinburgh: Churchill Livingstone Elsevier, 2007. 

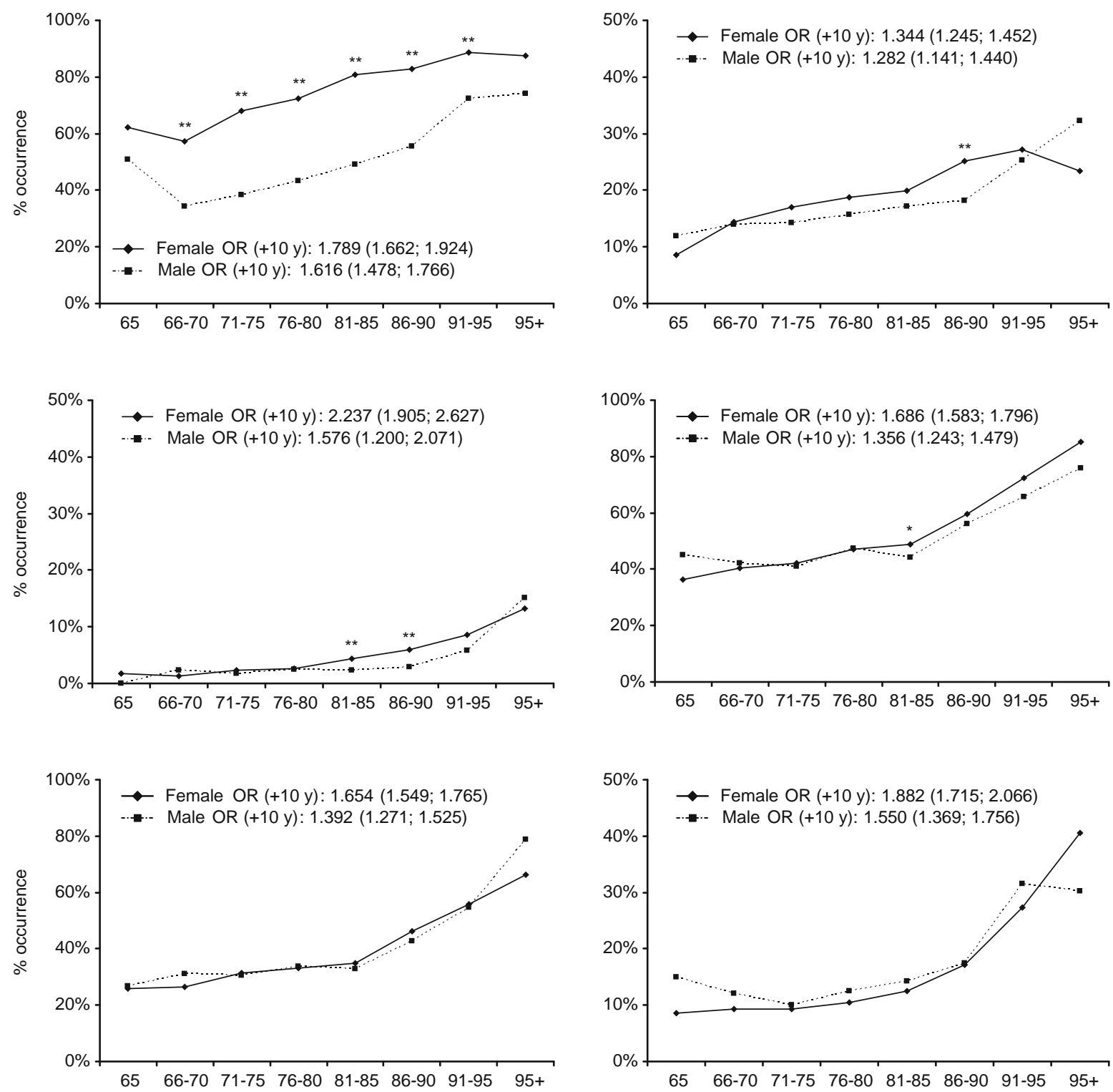

Age categories

Age categories

Fig. 3. Relationship between other syndromes occurrence and age. Significant difference between males and females (Fisher exact test) $* \mathbf{p}<$ $0.05, * * \mathrm{p}<0.01$. Statistical significance of gender and age as overall predictors of syndromes is based on logistic regression. $\mathrm{OR}=\mathrm{odds}-\mathrm{ratio}$ from the logistic regression for age change by 10 years; it shows how many times higher the odds for having given syndrome are when age changes by 10 years.

3. Williams ME. Geriatric physical diagnosis: a guide to observation and assessment. Jefferson N.C.: McFarland and Co., 2008.

4. Tinetti ME, Speechley M, Ginter SF. Risk factors for falls among elderly persons living in the community. NEJM 1988; 319: 1701-1707.

5. Harlein J, Dassen T, Halfens RJ, Heinze C. Fall risk factors in older people with dementia or cognitive impairment: a systematic review. J Adv Nurs 2009; 65: 922-933.

6. Oliver D, Daly F, Martin FC, McMurdo ME. Risk factors and risk assessment tools for falls in hospital in-patients: a systematic review. Age Ageing 2004; 33: 122-130.
7. Inouye S, Studenski S, Tinetti M et al. Geriatric syndromes: Clinical, research, and policy implications of a core geriatric concept. J Am Geriatr Soc 2007; 55: 780-791.

8. Pathy MSJ, Sinclair AJ, Morley JE (Eds). Principles and practice of geriatric medicine, 4th ed. Chichester; Wiley, 2006.

9. Durso S, Bowker L, Price J, Smith S (Eds). Oxford American Handbook of Geriatric Medicine. 1st edition. NY: Oxford University Press, USA, 2010.

10. Lakhan P, Jones M, Wilson A et al. A prospective cohort study of geriatric syndromes among older medical patients admitted to acute care hospitals. J Am Geriatr Soc 2011; 59: 2001-2008. 
$408-416$

11. Kellog International Work Group on the Prevention of Falls by the elderly. The prevention of falls in later life. A report of the Kellogg International Work Group on the Prevention of Falls by the Elderly. Dan Med J 1987; 34 (Suppl 4): 1-24.

12. Kruschinski C, Klaassen A, Breull A et al. Priorities of elderly dizzy patients in general practice. Findings and psychometric properties of the "Dizziness Needs Assessment” (DiNA). Z Gerontol Geriatr 2010; 43: 317-323.

13. Kenny RA, Bhangu J, King-Kallimanis BL. Epidemiology of syncope/ collapse in younger and older Western patient populations. Prog Cardiovasc Dis 2013; 55: 357-363.

14. Billington J, Fahey T, Galvin R. Diagnostic accuracy of the STRATIFY clinical prediction rule for falls: a systematic review and meta-analysis. BMC Fam Pract 2012; 7: $13-76$.

15. Ueno M, Kawai S, Mino T, Kamoshita H. Systematic review of fallrelated factors among the house-dwelling elderly in Japan. Nippon Ronen Igakkai Zasshi 2006; 43: 92-101.

16. Hsu CL, Nagamatsu LS, Davis JC, Liu-Ambrose T. Examining the relationship between specific cognitive processes and falls risk in older adults: a systematic review. Osteoporos Int 2012; 23: 2409-2424.

17. Muir SW, Gopaul K, Montero Odasso MM. The role of cognitive impairment in fall risk among older adults: a systematic review and metaanalysis. Age Ageing 2012; 41: 299-308.

18. Oliver D. Geriatric syndromes continue to be poorly managed and recognised. BMJ 2008; 337: 892.

19. Mecocci P, von Strauss E, Cherubini A et al. Cognitive impairment is the major risk factor for development of geriatric syndromes during hospitalization: results from the GIFA study. Dement Geriatric Cogn 2005; 20: 262-269.

20. Anstey KJ, von Sanden C, Luszcz MA. An 8-year prospective study of the relationship between cognitive performance and falling in very old adults. J Am Geriatr Soc 2006; 54: 1169-1176.

21. Gillespie LD, Gillespie WJ, Cumming $\mathbf{R}$ et al. Interventions for preventing falls in the elderly. Cochrane Database Syst Rev 2000; 2: CD000340.

22. Petridou ET, Manti EG, Ntinapogias AG et al. What works better for community-dwelling older people at risk to fall? A meta-analysis of multifactorial versus physical exercise-alone interventions. J Aging Health 2009; 21: 713-729.

23. Moayyeri A. The association between physical activity and osteoporotic fractures: a review of the evidence and implications for future research. Ann Epidemiol 2008; 18: 827-835.

24. Beswick AD, Rees K, Dieppe P et al. Complex interventions to improve physical function and maintain independent living in elderly people: a systematic review and meta-analysis. Lancet 2008; 371: 725-735.

25. Messinger-Rapport B, Dumas LG. Falls in the nursing home: a collaborative approach. Nurs Clin North Am 2009; 44: 187-195.

26. Pretorius RW, Gataric G, Swedlund SK, Miller JR. Reducing the risk of adverse drug events in older adults. Am Fam Phys 2013; 87: 331-336.

27. Fleming J, Brayne C. Cambridge City over-75s Cohort (CC75C) study collaboration. Inability to get up after falling, subsequent time on floor, and summoning help: prospective cohort study in people over 90. BMJ 2008; 337: a2227.

28. Moncada LV. Management of falls in older persons: a prescription for prevention. Am Fam Physician 2011; 84: 1267-1276.

29. Anders J, Dapp U, Laub S et al. Screening of fall risk in frail, but still independently living senior citizens. Z Gerontol Geriatr 2006; 39: 268-276.

30. Martin FC, Hart D, Spector T, Doyle DV, Harari D. Fear of falling limiting activity in young-old women is associated with reduced functional mobility rather than psychological factors. Age Ageing 2005; 34: 281-287.
31. Baumgarten M, Margolis DJ, Localio AR et al. Pressure ulcers among elderly patients early in the hospital stay. J Gerontol A Biol Sci Med Sci 2006; 61: 749-754.

32. Rantakokko M, Mänty M, Rantanen T. Mobility decline in old age. Exerc Sport Sci Rev 2013; 41 (1): 19-25.

33. Ohlendieck K. Proteomic Profiling of Fast-To-Slow Muscle Transitions during Aging. Front Physiol 2011; 2: 105.

34. Muhlberg W, Sieber C. Sarcopenia and frailty in geriatric patients: implications for training and prevention. Z Gerontol Geriatr 2004; 37: 2-8.

35. Jacobs JM, Maaravi Y, Cohen A et al. Changing profile of health and function from age 70 to 85 years. Gerontology 2012; 58: 313-321.

36. Rodriguez-Pascual C, Vilches-Moraga A, Paredes-Galán E et al. Comprehensive geriatric assessment and hospital mortality among older adults with decompensated heart failure. Am Heart J 2012; 164: 756-762.

37. Keeler E, Guralnik JM, Tian $\mathbf{H}$ et al. The impact of functional status on life expectancy in older persons. J Gerontol A Biol Sci Med Sci 2010; 65: 727-733.

38. Montero-Odasso M, Verghese J, Beauchet O, Hausdorff JM. Gait and cognition: a complementary approach to understanding brain function and the risk of falling. J Am Geriatr Soc 2012; 60: 2127-2136.

39. Wehrberger C, Madersbacher S, Jungwirth S et al. Lower urinary tract symptoms and urinary incontinence in a geriatric cohort - a population-based analysis. BJU Int 2012 Mar 12. doi: 10.1111/j.1464-410X.2012.11022.x.

40. Zullo MA, Ruggiero A, Montera $\mathbf{R}$ et al. An ultra-miniinvasive treatment for stress urinary incontinence in complicated older patients. Maturitas 2010; 65: 292-295.

41. Goode PS, Burgio KL, Redden DT, Markland A, Richter HE, Sawyer P, Allman RM. Population based study of incidence and predictors of urinary incontinence in black and white older adults. J Urol 2008; 179: 1449-1453.

42. Milsom I, Ekelund P, Molander $\mathbf{U}$ et al. The influence of age, parity, oral contraception, hysterectomy and menopause on the prevalence of urinary incontinence in women. J Urol 1993; 149: 1459-1462.

43. Hampel C, Thalroff JW, Gillitzer R. Epidemiology and etiology of male urinary incontinence. Urologe A 2010; 49 (4): 481-488.

44. Milsom I. Lower urinary tract symptoms in women. Curr Opin Urol 2009; 19: 337-341.

45. Igoumenou A, Ebmeier KP. Diagnosing and managing vascular dementia. Practitioner 2012; 256: 13-16.

46. Skoog I. Psychiatric disorders in the elderly. Can J Psychiatry 2011; 56: 387-397.

47. Duthie A, Chew D, Soiza RL. Non-psychiatric comorbidity associated with Alzheimer's disease. QJM 2011; 104: 913-920.

48. Jellinger KA, Attems J. Prevalence and pathology of vascular dementia in the oldest-old. J Alzheimers Dis 2010; 21: 1283-1293.

49. Wittchen HU, Jacobi F, Rehm $\mathbf{J}$ et al. The size and burden of mental disorders and other disorders of the brain in Europe 2010. Eur Neuropsychopharmacol 2011; 21: 655-679.

50. Kane RL, Shamliyan T, Talley K, Pacala J. The association between geriatric syndromes and survival. J Am Geriatr Soc 2012; 60: 896-904.

51. Landi F, Liperoti R, Lattanzio F et al. Effects of anorexia on mortality among older adults receiving home care: an observation study. JNHA 2012; 16: 79-83.

52. Han TS, Tajar A, Lean ME. Obesity and weight management in the elderly. Br Med Bull 2011; 97: 169-196. 